\title{
Bacillus thuringiensis Spores and Vegetative Bacteria: Infection Capacity and Role of the Virulence Regulon PlcR Following Intrahaemocoel Injection of Galleria mellonella
}

\author{
Christophe Buisson, Michel Gohar, Eugénie Huillet ${ }^{\dagger}$ and Christina Nielsen-LeRoux ${ }^{*}+{ }^{+}$(i) \\ Micalis Institute, INRA, AgroParisTech, Université Paris-Saclay, 78350 Jouy-en-Josas, France; \\ christophe.buisson@inra.fr (C.B.); michel.gohar@inra.fr (M.G.); eugenie.huillet@inra.fr (E.H.) \\ * Correspondence: Christina.nielsen-leroux@inra.fr; Tel.: +33-1-3465-2101 \\ t These authors contributed equally to this work.
}

Received: 19 March 2019; Accepted: 30 April 2019; Published: 5 May 2019

\begin{abstract}
Bacillus thuringiensis is an invertebrate pathogen that produces insecticidal crystal toxins acting on the intestinal barrier. In the Galleria mellonella larvae infection model, toxins from the PlcR virulence regulon contribute to pathogenicity by the oral route. While $B$. thuringiensis is principally an oral pathogen, bacteria may also reach the insect haemocoel following injury of the cuticle. Here, we address the question of spore virulence as compared to vegetative cells when the wild-type Bt407cry- strain and its isogenic $\Delta p l c R$ mutant are inoculated directly into G. mellonella haemocoel. Mortality dose-response curves were constructed at 25 and $37^{\circ} \mathrm{C}$ using spores or vegetative cell inocula, and the $50 \%$ lethal dose $\left(\mathrm{LD}_{50}\right)$ in all infection conditions was determined after $48 \mathrm{~h}$ of infection. Our findings show that (i) the $\mathrm{LD}_{50}$ is lower for spores than for vegetative cells for both strains, while the temperature has no significant influence, and (ii) the $\Delta p l c R$ mutant is four to six times less virulent than the wild-type strain in all infection conditions. Our results suggest that the environmental resistant spores are the most infecting form in haemocoel and that the PlcR virulence regulon plays an important role in toxicity when reaching the haemocoel from the cuticle and not only following ingestion.
\end{abstract}

Keywords: Bacillus thuringiensis; Galleria mellonella; haemocoel; spores; virulence; bio-pesticide; PlcR-regulon

\section{Introduction}

Bacillus thuringiensis strains are among the most widely used larvicidal entomopathogen [1]. B. thuringiensis is a member of the Bacillus cereus group, composed of several genetically closely related Gram positive and sporulating bacterial species [2,3], including the human opportunistic pathogen B. cereus, which is involved in food intoxication or more severe systemic infections [4]. B. cereus and $B$. thuringiensis are ubiquitously present in the environment. The major difference between $B$. cereus strains and $B$. thuringiensis is the presence of larvicidal crystal toxins in latter. The cry genes encoding these toxins are generally carried on large plasmids. Cry toxins are produced as inclusion bodies ("crystals") during the bacterial sporulation phase. Insecticidal action is initiated after ingestion of inclusion bodies by a susceptible larva, in which they are solubilized by the alkaline $\mathrm{pH}$ of the midgut, resulting in release of the protoxin, which is next processed by digestive enzymes to its active form. The activated toxin binds to several receptors on the gut epithelial surface resulting in pore formation, gut paralysis, decreased food uptake, and final death of the larva (for review $[5,6]$ ). Although the high toxicity of Cry toxins make them the most important virulence factors produced 
by $B$. thuringiensis, other factors also take part in the infection process. Indeed, in some insects and nematodes, full virulence requires the presence of spores and germinated vegetative bacteria in addition to Cry toxins. This is the case for Galleria mellonella, the greater wax moth [7]. Therefore, this insect is currently used as a model to explore various aspects of the B. thuringiensis infection process, including virulence and adaptation effectors, regulation networks involved in the production of these effectors, and the bacterium life cycle within the insect [8-12]. In this model, B. thuringiensis or B. cereus may be directly injected into the haemocoel, or can be administered by oral infection (force-feeding). In force-feeding, a mixture of vegetative cells and Cry1Ca toxin act in synergy to induce high larval mortality, whereas neither the bacteria nor the Cry1Ca toxin alone affects the larvae [13]. The strength of this synergy model was further proven when the assay, run with the $\Delta p l c R$ mutants of Bt 407 (crystal minus) or B. cereus ATCC 14579 strains, resulted in a strong decrease of insect mortality as compared to the wild-type strains. The PlcR protein is a transcriptional regulator (originally named as regulator of the gene encoding the phopholipase $\mathrm{C}$ ). PlcR is involved in activation and thus expression of a large number of secreted toxins and enzymes composing the PlcR regulon [14]. The PlcR regulon is required for bacterial pathogenicity, when spores are introduced via the oral route [13]. To be active, PlcR needs PapR, a signalling peptide, and these two factors comprise a quorum sensing system [15]. As observed with the $\Delta p l c R$ deletion strain, deletion of the papR gene strongly reduced virulence of B. thuringiensis strain 407cry- (crystal minus) in G. mellonella following oral infection [10]. Interestingly, virulence of the $\Delta p l c R$ mutant was reportedly not reduced after injection into haemocoel, leading Salamitou et al. 2000 [13] to suggest that the PlcR regulon is not required for pathogenicity when spores are mechanically introduced into the haemocoel. However, other studies indicated that some PlcR factors are expressed in the G. mellonella haemocoel $[9,12]$ and could be involved in infection, as reported by Bouillaut et al. 2005 [16]. In all previous virulence studies, using the G. mellonella model, infection tests by injection were either performed at $37^{\circ} \mathrm{C}[11,17]$ or at $25^{\circ} \mathrm{C}[10,13,18]$, and most of the time the infectious dose was delivered as either spores or vegetative cells but not both. It is; therefore, of interest to compare these two forms in the same study.

In the context of transmission of pathogens from one host to another, understanding the transfer of infection is essential to elucidate pathogenesis and as part of the pathogen's ecology. Horizontal transmission better fits to $B$. thuringiensis ecology than vertical transmission. Indeed, this pathogen kills its host and can grow and sporulate in the insect cadaver $[9,11,19]$. B. thuringiensis and to some extent $B$. cereus have a complex ecological cycle that may involve cycling between the insect larvae and the soil-plant environment [19-22], and the ecology of B. thuringiensis is still not fully understood [23].

Under natural conditions, the local density of spores and crystals can be low and for some strains the spore and crystal are separated following mother cell lysis. For these reasons, the probability to ingest spores and crystal together is likely to be low. In such conditions, and because the spore alone is inactive by the oral route, it might well be that infection from the cuticle, through spiracles or injury, has an underestimated role in $B$. thuringiensis persistence and transmission. Therefore, it is of relevance to further explore $B$. thuringiensis and $B$. cereus insect infection and virulence capacity, following haemocoel infection, which we here chose to do by performing experiments with the frequently used crystal minus B. thuringiensis strain, Bt407cry-.

This study has three objectives: (i) Evaluate and compare the virulence capacity of $B$. thuringiensis spores and vegetative cells following injection into the G. mellonella haemocoel; (ii) determine the impact of the infection temperature 37 versus $25^{\circ} \mathrm{C}$; and (iii) determine whether the PlcR regulon plays a role during haemocoel infection. The results should increase the knowledge of $B$. thuringiensis ecology and give clues on the relative role of secreted virulence factors from the PlcR regulon present in both B. thuringiensis and B. cereus strains. 


\section{Materials and Methods}

\subsection{Bacterial Strains and Cultures}

The study was carried out with the B. thuringiensis crystal minus strain Bt407cry- (referred to below as Bt407WT) and the interruption mutant Bt407cry- $\Delta p l c R,(\Delta p l c R$ mutant) as described in Salamitou et al. 2000 [13]. The $\Delta p l c R$ mutant is resistant to kanamycin $200 \mu \mathrm{g} / \mathrm{mL}$. B. thuringiensis cultures for vegetative cells were made in Luria-Bertani (LB) broth, incubated at $37{ }^{\circ} \mathrm{C}$, in 1:10 volume liquid:air flasks at $175 \mathrm{rpm}$. The vegetative bacteria used for infection were recovered from mid log phase $\left(\mathrm{Do}_{600}=1\right)$. Spore preparations for infection experiments were prepared in $100 \mathrm{~mL}$ (Hydrolysate of Casein and Tryptone) HCT -sporulation medium [24] in 1:10 volume liquid:air flasks at $175 \mathrm{rpm}$ at $30{ }^{\circ} \mathrm{C}$ until complete spore formation and cell lysis $(72 \mathrm{~h})$. Spores were collected by centrifugation as described previously [13], and resuspended in sterile water at $1 / 10$ of the initial volume, reaching about $3 \times 10^{7} \mathrm{cfu}$ (colony forming units)/mL, estimated following heating for $15 \mathrm{~min}$ at $78^{\circ} \mathrm{C}$ and from serial dilutions on LB agar plates.

\subsection{Mortality Tests in Galleria mellonella}

Haemocoel infection assays were performed with last instar G. mellonella larvae (250 mg), reared in our laboratory (INRA, Jouy-en-Josas or Versailles) on pollen and bee wax (La ruche Roannaise Besachier, Roanne, France). Larvae were injected using a syringe and needle with an injector pump KDS100 from KD Scientific, Thermo Fisher, Illkirch, France.

Each larva was inoculated with $10 \mu \mathrm{L}$ suspension of vegetative bacteria or spores from Bt407WT or $\Delta p l c R$ mutant strains. Mortality tests were performed using a range of doses (250-35,000 cfu per larva), appropriate to establish a full dose-response curve. Control larvae were injected with saline alone. A total of 25-30 larvae were infected per condition and tests were repeated at least three times. Larvae were incubated in small plastic dishes (5 per dish) without food at 25 or $37^{\circ} \mathrm{C}$. Mortality was scored at 48 hours post-treatment. Mortality rates were calculated by dividing the number of dead larvae by the number of total exposed larvae.

\subsection{Statistical Analysis}

The dataset from larval mortality, obtained at $48 \mathrm{~h}$, consisted of 131 observations obtained with the two strains (Bt407WT, $\Delta p l c R$ ), at 25 or $37^{\circ} \mathrm{C}$, and with spores or vegetative cells. Three to 4 biological replications and 4 to 5 doses were used per condition. The LD $_{50}$ (dose which kills $50 \%$ of totally treated larvae) values were determined by non-linear regression using the statistical software JMP9 (SAS Institute Inc., Cary, NC, USA). The model used for the regression was a derivative of the Hill equation $X^{n} / X^{n}+a^{n}$, where $x$ is the dose used and " $a$ " and " $n$ " are the computed parameters. The parameters, determined with their $95 \%$ confidence intervals $\left(\mathrm{CI}_{95} \%\right)$, represent the $\mathrm{LD}_{50}(\mathrm{a})$ and the steepness of the curve $(n)$. $\mathrm{LD}_{50}$ s were considered as significantly different, with $p<0.05$ for the null hypothesis, when the $\mathrm{CI}_{95} \%$ upper and lower confidence intervals did not overlap.

\section{Results}

\subsection{Relative Roles of Temperature, Spores, and Vegetative Bacteria in Virulence Tests}

Virulence results, $48 \mathrm{~h}$ after infection, from experiments performed on G. mellonella larvae with Bt407WT and $\triangle p l c R$ mutant strains are presented in Figures 1 and 2 and in Tables 1 and 2. Figure 1 shows all the mortality data obtained with Bt407WT and $\Delta p l c R$ mutant strain spores at 25 and $37^{\circ} \mathrm{C}$ (Figure 1A,B, respectively) and vegetative cells at 25 and $37^{\circ} \mathrm{C}$ (Figure $1 \mathrm{C}, \mathrm{D}$, respectively). The $\mathrm{LD}_{50}$ of the two strains were estimated with their $\mathrm{CI}_{95 \%}$ for all mortality test conditions (Tables 1 and 2 ). The $\mathrm{LD}_{50}$ of spores was about four times significantly $(p<0.05)$ lower than of the $\mathrm{LD}_{50}$ of vegetative cells at $37^{\circ} \mathrm{C}$, and about two times lower $(p<0.05)$ at $25^{\circ} \mathrm{C}$ (Tables 1 and 2 , Figure 2$)$. In contrast, no difference in $\mathrm{LD}_{50}$ was detected between 37 and $25^{\circ} \mathrm{C}$ incubation conditions when tested with 
spores or vegetative cells (Tables 1 and 2, Figure 2). Thus, the $\mathrm{LD}_{50}$ of both strains after G.mellonella intra-haemocoelic infection is independent of incubation conditions but dependent of the presence of spore or vegetative cell in the infectious dose.
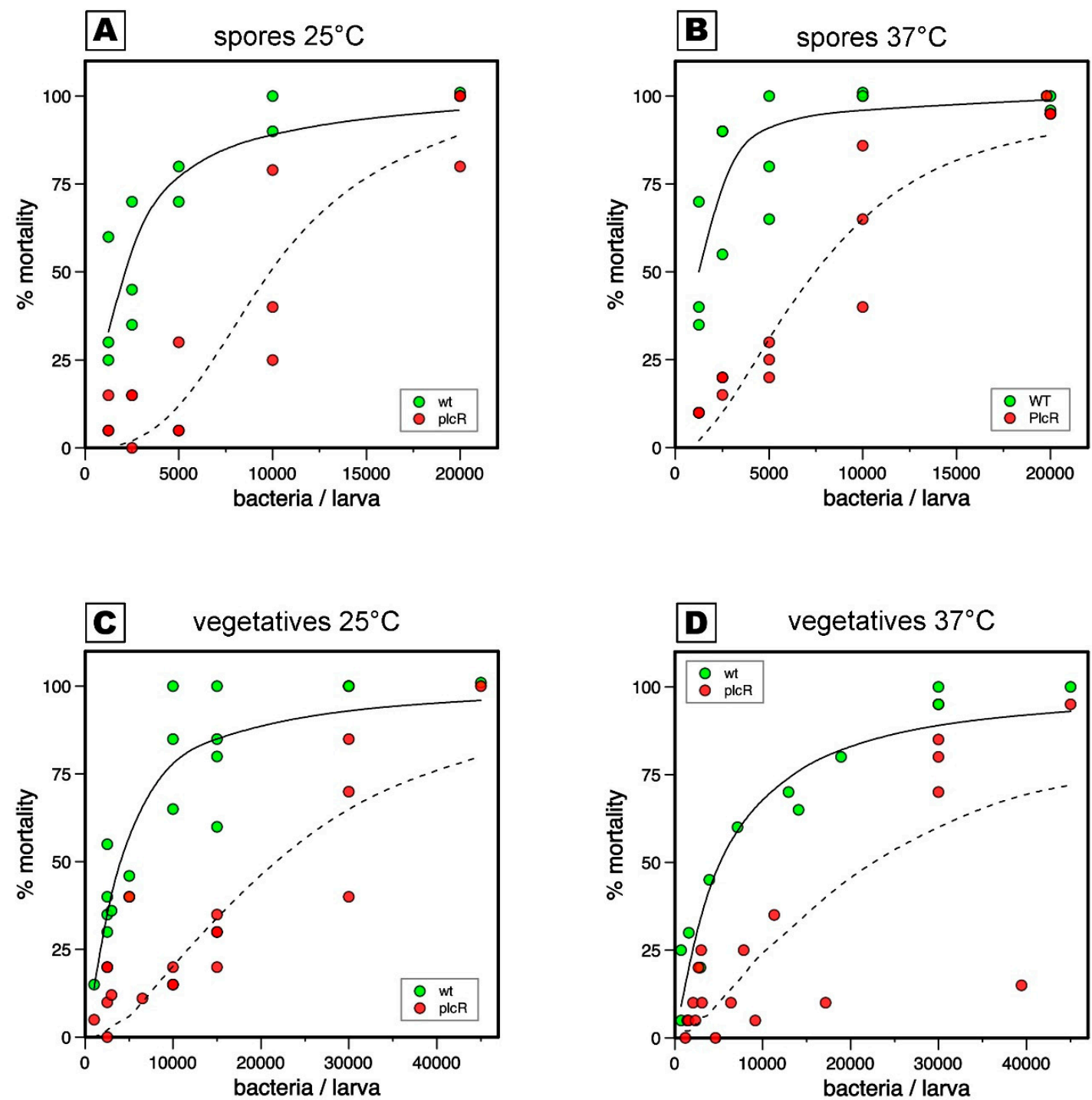

Figure 1. Dose-response mortality curves at $48 \mathrm{~h}$. Larvae mortalities are plotted against bacterial doses and are shown as green dots (WT), Bt407WT, or as red dots, $(p l c R) \Delta p l c R$ mutant. Non-linear regressions fitted to the experimental data are shown as plain lines (WT) or dotted lines (plcR). Mortalities at $48 \mathrm{~h}$ post-injection of spores at incubation temperature of $25^{\circ} \mathrm{C}(\mathbf{A})$ or $37^{\circ} \mathrm{C}(\mathrm{B})$. Mortalities post-injection of vegetative bacteria at $25^{\circ} \mathrm{C}(\mathrm{C})$ or $37^{\circ} \mathrm{C}$ (D).

Table 1. $50 \%$ Lethal dose ( $\mathrm{LD}_{50}$ values) and $95 \%$ confidence intervals $\left(\mathrm{CI}_{95 \%}\right)$ of Bt $407 \mathrm{WT}$ or $\Delta p l c R$ mutant strains estimated from mortality data following infection with spores.

\begin{tabular}{|c|c|c|c|c|}
\hline Temperature & Strain & $\mathrm{LD}_{50} *$ & {$\left[\mathrm{CI}_{\mathbf{9 5} \%}\right]$} & Ratio $\Delta p l c R$ Mutant v.s. Bt407WT \\
\hline \multirow[t]{2}{*}{$37^{\circ} \mathrm{C}$} & Bt407WT & 1261 & [606-1757] & \\
\hline & $\Delta p l c R$ mutant & 7344 & [5871-9050] & 5.8 \\
\hline \multirow[t]{2}{*}{$25^{\circ} \mathrm{C}$} & Bt407WT & 2088 & [1391-2873] & \\
\hline & $\Delta p l c R$ mutant & 9858 & [1015-7734] & 4.7 \\
\hline
\end{tabular}


Table 2. $50 \%$ Lethal dose ( $\mathrm{LD}_{50}$ values) and $95 \%$ confidence intervals $\left(\mathrm{CI}_{95 \%}\right)$ of Bt407WT or $\Delta p l c R$ mutant strains estimated from mortality data following infection with vegetative bacteria.

\begin{tabular}{|c|c|c|c|c|}
\hline Temperature & Strain & $\mathrm{LD}_{50}$ & {$\left[\mathrm{CI}_{95 \%}\right]$} & atio $\Delta p l c R$ Mutant vs. Bt407WT \\
\hline \multirow[t]{2}{*}{$37^{\circ} \mathrm{C}$} & Bt407WT & 5148 & [3618-7087] & \\
\hline & $\Delta p l c R$ mutant & 19,213 & {$[17,237-25,689]$} & 3.7 \\
\hline \multirow[t]{2}{*}{$25^{\circ} \mathrm{C}$} & Bt407WT & 4032 & [2981-5260] & \\
\hline & $\Delta p l c R$ mutant & 21,395 & {$[16,789-29,146]$} & 5.3 \\
\hline
\end{tabular}

${ }^{*} \mathrm{LD}_{50}$ : Dose of bacteria per larva, killing $50 \%$ of infected individuals.

3.2. The PlcR Regulon Is Required for Virulence When Spores or Vegetative Cells Are Mechanically Introduced into the Haemocoel

The $\mathrm{LD}_{50}$ of $\triangle p l c R$ mutant strain was about five times higher than that of Bt407WT when spores were used for mortality tests at both 37 and $25^{\circ} \mathrm{C}$. (Table 1, Figures 1 and 2). Additionally, the LD 50 of the $\Delta p l c R$ mutant was about four times higher than that of the wild-type strain when vegetative cells were used for mortality testing at both 37 and $25^{\circ} \mathrm{C}$. Therefore, in contrast with previous data [13], we found that the PlcR regulon is required for full Bt407WT virulence when spores or vegetative cells are mechanically introduced into the haemocoel.

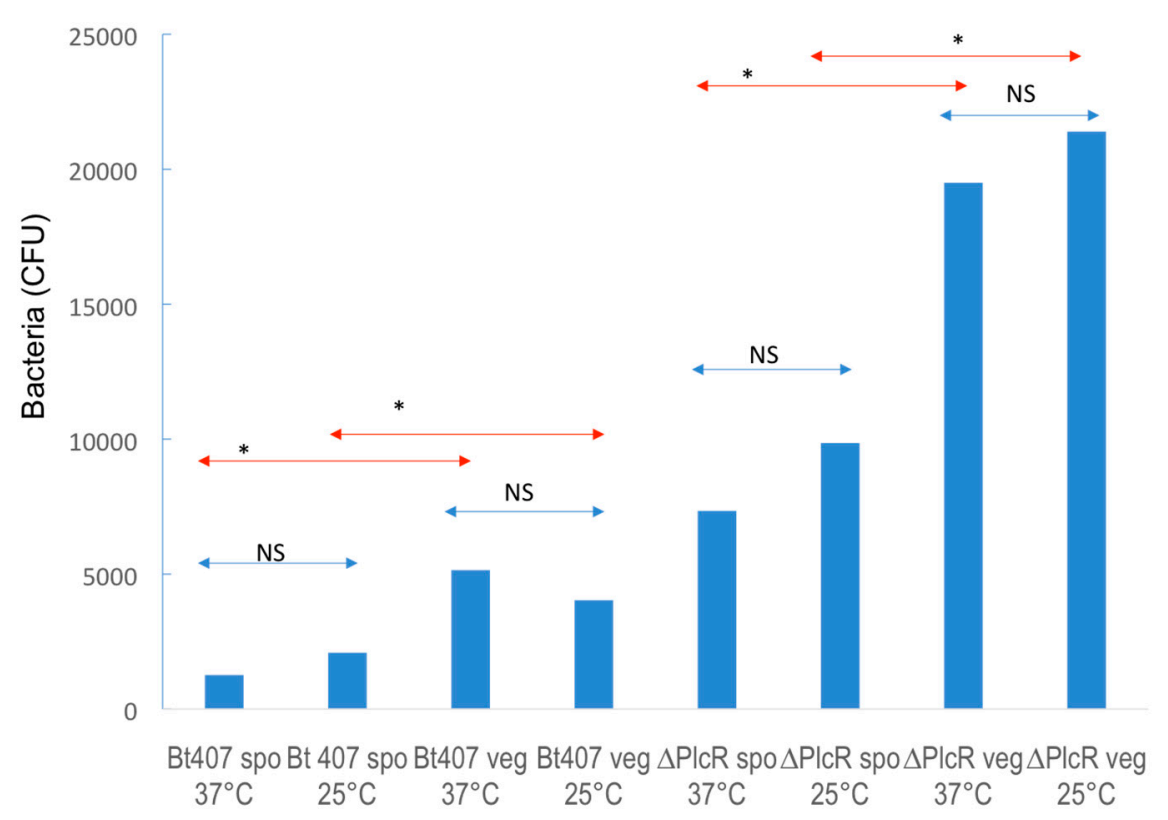

Figure 2. Temperature has no significant influence on the $\mathrm{LD}_{50}$. Comparisons between 25 and $37^{\circ} \mathrm{C}$ of $\mathrm{LD}_{50}$ values (represented as double arrow lines). Y-axis Bacteria (dose in CFU: colony forming units), $\mathrm{X}$-axis: various conditions). $\mathrm{LD}_{50}$ were considered as significantly different, with $p<0.05$ for the null hypothesis, when the $\mathrm{CI}_{95 \%}$ did not overlap. Non-significant (NS) (blue); significant ( ${ }^{*}$ red).

\section{Discussion}

One of the main issues of this study was to determine the relative infection capacity of spores versus vegetative bacteria from the Bt407WT strain after injection into the haemocoel of larvae of the insect G. mellonella. We also explored to what extent factors from the virulence regulon PlcR might be important for pathogenicity by this route, and if incubation temperature had an impact. To answer these questions, we set up a dose-response assay to calculate the different $\mathrm{LD}_{50}$. Our results indicate that whatever the condition or the strain, spores display a significantly lower $\mathrm{LD}_{50}$ than vegetative cells. The $\mathrm{LD}_{50}$ ratios between spores and vegetative cells were, for the Bt407WT strain, four fold at $37^{\circ} \mathrm{C}$ and two fold at $25^{\circ} \mathrm{C}$, while for the $\Delta p l c R$ mutant strain, the ratio was close to two at both 
temperatures. This indicates that under the conditions of our study, spores are more infective than vegetative bacteria for both strains. When comparing, Bt407WT and $\Delta p l c R$ stains, larval mortality was recorded at 24, 48, and $72 \mathrm{~h}$ post injection (data not shown for 24 and $72 \mathrm{~h}$ ). We chose to show the data at $48 \mathrm{~h}$ only, as the plateau of the $\mathrm{LD}_{50}$ was reached at this time point. Indeed, at $24 \mathrm{~h}$ the ratios between the two strains was higher, but no difference was found between the strains at 48 and $72 \mathrm{~h}$ post injection. Therefore, is seems like at a given dose the $\Delta p l c R$ mutant would not reach the Bt407WT strain virulence, even after a longer infection time in our model.

Several hypotheses could explain that spores are more virulent than vegetative cells to G. mellonella when inoculated by injection. When bacteria reach the haemocoel, they face the basic innate cellular and humoral immune responses of their host. While the vegetative form can be directly damaged by antimicrobial peptides or proteins, such as lysozyme, gallerimycin, or gloverin [25], the spores are not affected until germination by these molecules. Another response of the host lays in the production of phenol oxidase and clotting factors, which should act faster towards vegetative bacteria through their liberation of PAMP (pathogen-associated molecular pattern) than towards spores [26,27]. Therefore, host responses might be different at a later time point of infection, or the spores possess a factor that blocks part of the immune response. On the other hand, spores might be more easily phagocytosed by specialized hemocytes and could, thus, be damaged $[25,28]$. Meanwhile, according to a study using mammalian phagocytes, spores of Bt407WT were able to geminate and multiply inside macrophages [29], and Dubovskiy et al. [28] showed phagocytosis of a vegetative B. thuringiensis strain following oral infection of G. mellonella, but no information related to spore versus vegetative bacteria was reported in that paper. Another hypothesis to explain the greater virulence of spores is that they could constitute a reservoir of continuously released vegetative cells, which at the end would overcome host defenses. Alternatively, spores could concentrate, through its adhesion capabilities, on specific tissues, which would then be strongly damaged by secreted virulence factors after germination. A histopathological study designed to follow the fate of spores in the larval body could help distinguish between the different hypotheses.

Our results are in disagreement with conclusions of a previous study, in which the PlcR virulence regulon was found to have no effect on bacterial virulence when injected into the haemocoel of G. mellonella [13]. However, in our study, both spores and vegetative bacteria from the $\Delta p l c R$ mutant are about five-fold less virulent than Bt407WT at both temperatures. Perhaps in the former assays the number of repetitions and doses were lower, although the $\mathrm{LD}_{50}$ was determined by Probit. Here we used several doses and determined the $\mathrm{LD}_{50}$ by a statistical method (non-linear regression), which takes into account all doses for the $\mathrm{LD}_{50}$ calculation. In addition, our results are supported by other studies; for instance, the supernatant from the $\Delta$ plcR mutant was less cytotoxic to Galleria hemocytes than the supernatant from the Bt407WT culture [13], and some genes from the PlcR regulon are expressed in the haemocoel of $G$. mellonella $(p l c B, m p b E)[9,12]$, although expression does not prove a role in infection and virulence. The role of PlcR in G. mellonella infected by the oral route was previously shown to be strong, since spores of the $\Delta p l c R$ mutant killed only $10 \%$ of the larvae, while the same dose of spores from the wild-type strain killed 70\% of the larvae [13]. In a similar study, one of the PlcR-regulated factors, the metalloprotease InhA2 was shown to have a major role in virulence [30] after oral infection. Additionally, other PlcR-regulated genes were shown to be important for B. thuringiensis virulence against insects by ingestion, including a collagenase [31] or the Enhancin-like Bel protease [32]. In contrast, the role of PlcR in B. thuringiensis virulence against the nematode Caenorhabditis elegans after ingestion of bacteria seems to be weak [33]. Therefore, we have actually more clues on the implication of individual genes from the PlcR regulon following oral infection than by haemocoel infection. Further studies are needed to identify factors of the PlcR regulon that play major roles in the haemocoel; this issue should be investigated in correlation with the innate cell and humoral host responses.

Our study shows that environment-resistant spores of $B$. thuringiensis are also the most efficient at infecting G. mellonella, even in the haemocoel. At present, the study is conducted in the laboratory with relatively high doses. It will be interesting to set up experiments in more natural conditions and with 
other insects and strains. Indeed, for instance G. mellonella is much less susceptible to Bt407WT than Bombyx mori, for which a very small amount of bacteria introduced into the haemocoel kill large fifth instars [34]. Likewise, it would be important to test the outcome of spores versus vegetative bacteria in Galleria infected with a crystal producing strain active to this insect [25].

As mentioned in the introduction it is triggering that, for several B. thuringiensis strains, the spores and toxin crystal dissociate after mother cell lysis, while other B. thuringiensis strains are reported to keep the inclusion body inside the exosporium [35]. Whether it is the case for the strain naturally toxic to G. mellonella [25] or those reported in Li et al. 1987 [7] remains to be studied. In addition, the relative role of the PlcR-PapR quorum sensing systems [15] was analyzed from an ecological issue in Plutella xylostella (Diamondback Moth) [36]: in this insect, results also indicated that this system is important to fulfil infection and sporulation. Altogether our study contributes further to the role of the PlcR regulon in insect virulence and raises questions on the importance of spores in infection from the cuticle site for B. thuringiensis persistence and transmission.

\section{Conclusions}

We studied the role of two infective forms of $B$. thuringiensis following injection into the haemocoel of G. mellonella. Our results show that by this infection route i) spores are more virulent than vegetative bacteria, and ii) factors controlled by the PlcR regulator are involved in pathogenesis and larval mortality. This indicates that the common virulence factors of B. thuringiensis and B. cereus strains may take part in pathogenesis both through the cuticle and following ingestion. These findings offer valuable perspectives for the development of ecological and epidemiological models of $B$. thuringiensis infections.

Author Contributions: Conceptualization, C.N.-L., and E.H.; methodology, C.N.-L., C.B.; software, C.N.-L., M.G., E.H.; validation, C.N.-L., E.H. and M.G.; formal analysis, C.N.-L., E.H., M.G.; investigation, C.N.-L., C.B., resources, C.B., C.N.-L. data C.N.-L., E.H., M.G., writing-original draft preparation, C.N.-L., E.H. writing-review and editing, C.N.-L., E.H., M.G.

Funding: This research received no specific external funding but was supported by INRA and the MICA department.

Acknowledgments: The authors thank Didier Lereclus, and our present and former colleagues from the GME (Génétique microbienne \& Environnement) team, for their inspiring work on the many facets related to the PlcR quorum sensing system. The authors are grateful to Alexandra Gruss for English improvement.

Conflicts of Interest: The authors declare no conflict of interest.

\section{References}

1. Sanahuja, G.; Banakar, R.; Twyman, R.M.; Capell, T.; Christou, P. Bacillus thuringiensis: a century of research, development and commercial applications. Plant Biotechnol. J. 2011, 9, 283-300. [PubMed]

2. Kolsto, A.B.; Tourasse, N.J.; Okstad, O.A. What sets Bacillus anthracis apart from other Bacillus species? Annu. Rev. Microbiol. 2009, 63, 451-476. [CrossRef]

3. Patino-Navarrete, R.; Sanchis, V. Evolutionary processes and environmental factors underlying the genetic diversity and lifestyles of Bacillus cereus group bacteria. Res. Microbiol. 2017, 168, 309-318. [CrossRef]

4. Bottone, E.J. Bacillus cereus, a volatile human pathogen. Clin. Microbiol. Rev. 2010, 23, 382-398. [CrossRef]

5. Bravo, A.; Likitvivatanavong, S.; Gill, S.S.; Soberon, M. Bacillus thuringiensis: A story of a successful bioinsecticide. Insect Biochem. Mol. Biol. 2011, 41, 423-431. [CrossRef] [PubMed]

6. Vachon, V.; Laprade, R.; Schwartz, J.L. Current models of the mode of action of Bacillus thuringiensis insecticidal crystal proteins: a critical review. J. Invertebr. Pathol. 2012, 111, 1-12. [CrossRef]

7. Li, R.S.; Jarrett, P.; Burges, H.D. Importance of spores, crystals, and $\partial$-endotoxins in the pathogenicity of different varieties of Bacillus thuringiensis in Galleria mellonela and Pieris brassicae. J. Invertebr. Pathol. 1987, 50, 277-284. [CrossRef]

8. Nielsen-LeRoux, C.; Gaudriault, S.; Ramarao, N.; Lereclus, D.; Givaudan, A. How the insect pathogen bacteria Bacillus thuringiensis and Xenorhabdus/Photorhabdus occupy their hosts. Curr. Opin. Microbiol. 2012, 15, 220-231. [CrossRef] 
9. Dubois, T.; Faegri, K.; Perchat, S.; Lemy, C.; Buisson, C.; Nielsen-LeRoux, C.; Gohar, M.; Jacques, P.; Ramarao, N.; Kolsto, A.B.; et al. Necrotrophism is a quorum-sensing-regulated lifestyle in Bacillus thuringiensis. PLoS Pathog. 2012, 8, e1002629. [CrossRef] [PubMed]

10. Slamti, L.; Lereclus, D. A cell-cell signaling peptide activates the PlcR virulence regulon in bacteria of the Bacillus cereus group. EMBO J. 2002, 21, 4550-4559. [CrossRef]

11. Dubois, T.; Faegri, K.; Gelis-Jeanvoine, S.; Perchat, S.; Lemy, C.; Buisson, C.; Nielsen-LeRoux, C.; Gohar, M.; Jacques, P.; Ramarao, N.; et al. Correction: Necrotrophism Is a Quorum-Sensing-Regulated Lifestyle in Bacillus thuringiensis. PLoS Pathog. 2016, 12, e1006049. [CrossRef]

12. Verplaetse, E.; Slamti, L.; Gohar, M.; Lereclus, D. Cell Differentiation in a Bacillus thuringiensis Population during Planktonic Growth, Biofilm Formation, and Host Infection. MBio. 2015, 6, e00138-15. [CrossRef]

13. Salamitou, S.; Ramisse, F.; Brehelin, M.; Bourguet, D.; Gilois, N.; Gominet, M.; Hernandez, E.; Lereclus, D. The plcR regulon is involved in the opportunistic properties of Bacillus thuringiensis and Bacillus cereus in mice and insects. Microbiology 2000, 146, 2825-2832. [CrossRef]

14. Gohar, M.; Faegri, K.; Perchat, S.; Ravnum, S.; Okstad, O.A.; Gominet, M.; Kolsto, A.B.; Lereclus, D. The PlcR virulence regulon of Bacillus cereus. PLoS ONE 2008, 3, e2793. [CrossRef]

15. Slamti, L.; Perchat, S.; Huillet, E.; Lereclus, D. Quorum sensing in Bacillus thuringiensis is required for completion of a full infectious cycle in the insect. Toxins (Basel) 2014, 6, 2239-2255. [CrossRef] [PubMed]

16. Bouillaut, L.; Ramarao, N.; Buisson, C.; Gilois, N.; Gohar, M.; Lereclus, D.; Nielsen-Leroux, C. FlhA influences Bacillus thuringiensis PlcR-regulated gene transcription, protein production, and virulence. Appl. Environ. Microbiol. 2005, 71, 8903-8910. [CrossRef]

17. Candela, T.; Fagerlund, A.; Buisson, C.; Gilois, N.; Kolsto, A.B.; Okstad, O.A.; Aymerich, S.; Nielsen-Leroux, C.; Lereclus, D.; Gohar, M. CalY is a major virulence factor and a biofilm matrix protein. Mol. Microbiol. 2018. [CrossRef]

18. Gominet, M.; Slamti, L.; Gilois, N.; Rose, M.; Lereclus, D. Oligopeptide permease is required for expression of the Bacillus thuringiensis plcR regulon and for virulence. Mol. Microbiol. 2001, 40, 963-975. [CrossRef] [PubMed]

19. Raymond, B.; Elliot, S.L.; Ellis, R.J. Quantifying the reproduction of Bacillus thuringiensis HD1 in cadavers and live larvae of Plutella xylostella. J. Invertebr. Pathol. 2008, 98, 307-313. [CrossRef]

20. Jensen, G.B.; Hansen, B.M.; Eilenberg, J.; Mahillon, J. The hidden lifestyles of Bacillus cereus and relatives. Environ. Microbiol. 2003, 5, 631-640. [CrossRef] [PubMed]

21. Ceuppens, S.; Boon, N.; Uyttendaele, M. Diversity of Bacillus cereus group strains is reflected in their broad range of pathogenicity and diverse ecological lifestyles. FEMS Microbiol. Ecol. 2013, 84, 433-450. [CrossRef]

22. Raymond, B.; Johnston, P.R.; Nielsen-LeRoux, C.; Lereclus, D.; Crickmore, N. Bacillus thuringiensis: An impotent pathogen? Trends Microbiol. 2010, 18, 189-194. [CrossRef]

23. Argolo-Filho, R.C.; Loguercio, L.L. Bacillus thuringiensis Is an Environmental Pathogen and Host-Specificity Has Developed as an Adaptation to Human-Generated Ecological Niches. Insects 2013, 5, 62-91. [CrossRef]

24. Lecadet, M.M.; Blondel, M.O.; Ribier, J. Generalized transduction in Bacillus thuringiensis var. berliner 1715 using bacteriophage CP-54Ber. J. Gen. Microbiol. 1980, 121, 203-212. [CrossRef]

25. Dubovskiy, I.M.; Grizanova, E.V.; Whitten, M.M.; Mukherjee, K.; Greig, C.; Alikina, T.; Kabilov, M.; Vilcinskas, A.; Glupov, V.V.; Butt, T.M. Immuno-physiological adaptations confer wax moth Galleria mellonella resistance to Bacillus thuringiensis. Virulence 2016, 7, 860-870. [CrossRef]

26. Wojda, I. Immunity of the greater wax moth Galleria mellonella. Insect Sci. 2017, 24, 342-357. [CrossRef]

27. Vogel, H.; Altincicek, B.; Glockner, G.; Vilcinskas, A. A comprehensive transcriptome and immune-gene repertoire of the lepidopteran model host Galleria mellonella. BMC Genom. 2011, 12, 308. [CrossRef]

28. Dubovskiy, I.M.; Krukova, N.A.; Glupov, V.V. Phagocytic activity and encapsulation rate of Galleria mellonella larval haemocytes during bacterial infection by Bacillus thuringiensis. J. Invertebr. Pathol. 2008, 98, 360-362. [CrossRef]

29. Ramarao, N.; Lereclus, D. The InhA1 metalloprotease allows spores of the B. cereus group to escape macrophages. Cell. Microbiol. 2005, 7, 1357-1364. [CrossRef]

30. Fedhila, S.; Nel, P.; Lereclus, D. The InhA2 metalloprotease of Bacillus thuringiensis strain 407 is required for pathogenicity in insects infected via the oral route. J. Bacteriol. 2002, 184, 3296-3304. [CrossRef] 
31. Peng, D.; Lin, J.; Huang, Q.; Zheng, W.; Liu, G.; Zheng, J.; Zhu, L.; Sun, M. A novel metalloproteinase virulence factor is involved in Bacillus thuringiensis pathogenesis in nematodes and insects. Environ. Microbiol. 2016, 18, 846-862. [CrossRef]

32. Fang, S.; Wang, L.; Guo, W.; Zhang, X.; Peng, D.; Luo, C.; Yu, Z.; Sun, M. Bacillus thuringiensis bel protein enhances the toxicity of Cry1Ac protein to Helicoverpa armigera larvae by degrading insect intestinal mucin. Appl. Environ. Microbiol. 2009, 75, 5237-5243. [CrossRef] [PubMed]

33. Kho, M.F.; Bellier, A.; Balasubramani, V.; Hu, Y.; Hsu, W.; Nielsen-LeRoux, C.; McGillivray, S.M.; Nizet, V.; Aroian, R.V. The pore-forming protein Cry5B elicits the pathogenicity of Bacillus sp. against Caenorhabditis elegans. PLoS ONE 2011, 6, e29122. [CrossRef]

34. Fedhila, S.; Guillemet, E.; Nel, P.; Lereclus, D. Characterization of two Bacillus thuringiensis genes identified by in vivo screening of virulence factors. Appl. Environ. Microbiol. 2004, 70, 4784-4791. [CrossRef] [PubMed]

35. Zhu, Y.; Ji, F.; Shang, H.; Zhu, Q.; Wang, P.; Xu, C.; Deng, Y.; Peng, D.; Ruan, L.; Sun, M. Gene clusters located on two large plasmids determine spore crystal association (SCA) in Bacillus thuringiensis subsp. finitimus strain YBT-020. PLoS ONE 2011, 6, e27164. [CrossRef] [PubMed]

36. Zhou, L.; Slamti, L.; Nielsen-LeRoux, C.; Lereclus, D.; Raymond, B. The social biology of quorum sensing in a naturalistic host pathogen system. Curr. Biol. 2014, 24, 2417-2422. [CrossRef] [PubMed]

(C) 2019 by the authors. Licensee MDPI, Basel, Switzerland. This article is an open access article distributed under the terms and conditions of the Creative Commons Attribution (CC BY) license (http://creativecommons.org/licenses/by/4.0/). 